\title{
Antioxidant activities and phenolic contents of the methanol extracts of the stems of Acokanthera oppositifolia and Adenia gummifera
}

\author{
Adeolu A Adedapo* ${ }^{* 1}$, Florence O Jimoh ${ }^{\dagger 2}$, Anthony J Afolayan ${ }^{\dagger 2}$ and \\ Patrick J Masika ${ }^{\dagger 3}$
}

Address: ${ }^{1}$ Department of Veterinary Physiology, Biochemistry and Pharmacology, University of Ibadan, Ibadan, Nigeria, ${ }^{2}$ Department of Botany, University of Fort Hare, Alice 5700, South Africa and ${ }^{3}$ ARDRI, University of Fort Hare, Alice 5700, South Africa

Email: Adeolu A Adedapo* - adedapo3a@yahoo.co.uk; Florence O Jimoh - asjimoh02@yahoo.com; Anthony J Afolayan - aafolayan@ufh.ac.za; Patrick J Masika - pmasika@ufh.ac.za

* Corresponding author †Equal contributors

Published: 25 September 2008

BMC Complementary and Alternative Medicine 2008, 8:54 doi:10.1 186//472-6882-8-54
Received: 30 May 2008

Accepted: 25 September 2008

This article is available from: http://www.biomedcentral.com/l472-6882/8/54

(C) 2008 Adedapo et al; licensee BioMed Central Ltd.

This is an Open Access article distributed under the terms of the Creative Commons Attribution License (http://creativecommons.org/licenses/by/2.0), which permits unrestricted use, distribution, and reproduction in any medium, provided the original work is properly cited.

\begin{abstract}
Background: Acokanthera oppositifolia Lam (family: Apocynaceae) is a shrub or small tree with white latex, and the leaves of this plant are used in the form of a snuff to treat headaches and in infusions for abdominal pains and convulsions and septicaemia. Adenia gummifera Harv of the family Passifloraceae is a distinctive woody climber whose infusions are used as emetics and are said to help with some forms of depression. Lipid peroxidation has gained more importance today because of its involvement in pathogenesis of many diseases. Free radicals are the main agents in lipid peroxidation. Antioxidants thus play an important role of protecting the human body against damage by the free radicals. Plants containing phenolic compounds have been reported to possess strong antioxidant properties.
\end{abstract}

Methods: The antioxidant activities and phenolic contents of the methanol extracts of the stems of Acokanthera oppositifolia and Adenia gummifera were evaluated using in vitro standard procedures. Spectrophotometry was the basis for the determinations of total phenol, total flavonoids, flavonols, and proanthocyanidins. Tannins, quercetin and catechin equivalents were used for these parameters. The antioxidant activities of the stem extract of Acokanthera oppositifolia were determined by the 2,2'-azinobis-3- ethylbenzothiazoline-6-sulfonic acid (ABTS), I, IDiphenyl-2-picrylhydrazyl (DPPH), and ferrous reducing antioxidant property (FRAP) methods.

Results: The results from this study showed that the antioxidant activities of the stem extract of Acokanthera oppositifolia as determined by the I,I-Diphenyl-2-picrylhydrazyl (DPPH), and ferrous reducing antioxidant property (FRAP) methods, were higher than that of Adenia gummifera. The levels of total phenols and flavonols for A. oppositifolia were also higher. On the other hand, the stem extract of Adenia gummifera had higher level of total flavonoids and proanthocyanidins than that of Acokanthera oppositifolia. The 2, 2'-azinobis-3ethylbenzothiazoline-6-sulfonic acid (ABTS) activities of the 2 plant extracts were similar and comparable to that of $\mathrm{BHT}$.

Conclusion: Thus, the present results indicate clearly that the extracts of Acokanthera oppositifolia and Adenia gummifera possess antioxidant properties and could serve as free radical inhibitors or scavengers, acting possibly as primary antioxidants. This study has to some extent validated the medicinal potential of the stems of Acokanthera oppositifolia and Adenia gummifera. 


\section{Background}

Acokanthera oppositifolia Lam (family: Apocynaceae) is a shrub or small tree with white latex, thick leathery leaves, attractive white flowers and red berries which turn dark purple when ripen. The latex, fruit and decoctions of the wood of this plant were widely used as arrow poisoning in southern Africa. These plant parts can sometimes be combined with Euphorbia latex, the sap of Acacia mellifera and the venom from the poison glands of snake and used as arrow poisoning. In the Northern Cape of South Africa, arrows poisoned with Acokanthera and snake venom were used to kill antelope and buffalo, and against enemies [1-4]. Poisoning of animals by this plant is surprisingly rare but cattle are sometimes at risk during droughts [5].

The leaves of this plant are used in the form of a snuff to treat headaches and in infusions for abdominal pains and convulsions and septicaemia. Powdered roots are administered orally or as snuff to treat pain and snake-bite and root decoctions are used against anthrax and tapeworm $[4,6,7]$. The leaves of this plant when boiled in water for ten minutes, strained and left to stand overnight are given to goats and sheep $(200 \mathrm{ml})$ to treat heart water disease [7]. Members of the genus Acokanthera contain several toxic cardiac glycosides such as ouabain $[4,8,9]$. Acovenoside, a cardiac glycoside, is the major toxic component of both A. oppositifolia and A. oblongifolia [4].

Adenia gummifera Harv of the family Passifloraceae is a distinctive woody climber with bright green stems and lobed leaves. Infusions are used as emetics and are said to help with some forms of depression. Though the thick, green stem is said to be very poisonous but is popular for treating of leprosy and malaria $[4,6]$. Species of Adenia have been used as fish poisons [2] and have also been implicated in stock losses, homicide and suicide $[1,2,4,5]$. The toxicity of Adenia species is due to the combination of a highly toxic protein, modeccin, and cyanogenic glycosides [4,10-12]. Gummiferol, a cytotoxic polyacetylenic diepoxide was isolated from the leaves of Adenia gummifera by KB cytotoxicity-guided fractionation and this compound exhibited significant activity against the KB human cell line and a broad cytotoxic spectrum against other human cancer cell lines [13]. KB or NFKB is nuclear activated kappa $B$, and is a transcription factor that has a key role in the induction of inflammatory and immune response [14].

Lipid peroxidation has gained more importance today because of its involvement in pathogenesis of many diseases like atherosclerosis, cancer, diabetes mellitus, myocardial infarction, and also ageing. Free radicals or reactive oxygen species (ROS) are produced in vivo from various biochemical reactions and also from the respiratory chain as a result of occasional leakage. These free radicals are the main agents in lipid peroxidation [15]. Antioxidants thus play an important role of protecting the human body against damage by reactive oxygen species $[16,17]$. Plants containing phenolic compounds, in particular flavonoids have been reported to possess strong antioxidant properties $[18,19]$.

In the present study, the methanol extracts of the stem of Acokanthera oppositifolia and Adenia gummifera were screened for antioxidant properties using in vitro standard procedures so as to assess the medicinal potential of these 2 plants and thus justify their folklore use.

\section{Methods \\ Plant collection}

The plants were collected in July 2006 from some villages in the Eastern Cape Province of South Africa. The area falls within the latitudes $30^{\circ} 00-34^{\circ} 15^{\prime} \mathrm{S}$ and longitudes $22^{\circ}$ $45^{\prime}-30^{\circ} 15^{\prime} \mathrm{E}$. It is bounded by the sea in the east and the drier Karoo (semi-desert vegetation) in the west [20]. These areas consist of villages which are generally classified as rural and poor. The plants were identified by their vernacular names and later validated at the Department of Botany, University of Fort Hare and voucher specimens (Aded Med 2007/1-10) were deposited in the Griffen Herbarium of the University.

\section{Extract preparation}

Plants were air dried at room temperature for 3 weeks to get consistent weight. The dried plants were later ground to powder. Two hundred grams of ground plant material were shaken separately in methanol for $48 \mathrm{hrs}$ on an orbital shaker at room temperature. Extracts were filtered using a Buckner funnel and Whatman No 1 filter paper. Each filtrate was concentrated to dryness under reduced pressure at $40^{\circ} \mathrm{C}$ using a rotary evaporator. Each extract was resuspended in the respective solvent, methanol, to yield a $50 \mathrm{mg} / \mathrm{ml}$ stock solution [21].

\section{Chemicals}

1,1-Diphenyl-2-picrylhydrazyl (DPPH), 2,2'-azinobis-3ethylbenzothiazoline-6-sulfonic acid (ABTS), 3-(2-pyridyl)-5,6-diphenyl-1,2,4-triazine-4',4"-disulfonic acid, potassium ferricyanide; catechin, butylated hydroxytoluene (BHT), ascorbic acid, catechin, tannic acid, quercetin and $\mathrm{FeCl}_{3}$ were purchased from Sigma Chemical Co. (St. Louis, MO, USA)., vanillin from BDH; Folin-Ciocalteus's phenol reagent and sodium carbonate were from Merck Chemical Supplies (Damstadt, Germany). All the other chemicals used including the solvents, were of analytical grade. 


\section{Determination of total phenolics}

Total phenolic contents in the extracts were determined by the modified Folin-Ciocalteu method [22]. An aliquot of the extracts was mixed with $5 \mathrm{ml}$ Folin-Ciocalteu reagent (previously diluted with water $1: 10 \mathrm{v} / \mathrm{v})$ and $4 \mathrm{ml}(75$ $\mathrm{g} / \mathrm{l}$ ) of sodium carbonate. The tubes were vortexed for 15 sec and allowed to stand for $30 \mathrm{~min}$ at $40^{\circ} \mathrm{C}$ for color development. Absorbance was then measured at $765 \mathrm{~nm}$ using the Hewlett Packard UV-VIS spectrophotometer. Samples of extract were evaluated at a final concentration of $0.1 \mathrm{mg} / \mathrm{ml}$. Total phenolic content was expressed as $\mathrm{mg} / \mathrm{g}$ tannic acid equivalent using the following equation based on the calibration curve: $y=0.1216 \mathrm{x}, \mathrm{R}^{2}=0.9365$, where $\mathrm{x}$ was the absorbance and $\mathrm{y}$ was the tannic acid equivalent $(\mathrm{mg} / \mathrm{g})$.

\section{Determination of total Flavonoids}

Total flavonoid contents were determined using the method of Ordon ez et al., [23] of sample solution. A volume of $0.5 \mathrm{ml}$ of $2 \% \mathrm{AlCl}_{3}$ ethanol solution was added to $0.5 \mathrm{ml}$ of sample solution. After one hour at room temperature, the absorbance was measured at $420 \mathrm{~nm}$. A yellow color indicated the presence of flavonoids. Extract samples were evaluated at a final concentration of $0.1 \mathrm{mg} / \mathrm{ml}$. Total flavonoid content were calculated as quercetin (mg/ g) using the following equation based on the calibration curve: $y=0.0255 \mathrm{x}, \mathrm{R}^{2}=0.9812$, where $\mathrm{x}$ was the absorbance and was the quercetin equivalent $(\mathrm{mg} / \mathrm{g})$.

\section{Determination of total Flavonols}

Total flavonols in the plant extracts were estimated using the method of Kumaran and Karunakaran [24]. To $2.0 \mathrm{~mL}$ of sample (standard), $2.0 \mathrm{~mL}$ of $2 \% \mathrm{AlCl}_{3}$ ethanol and 3.0 $\mathrm{mL}(50 \mathrm{~g} / \mathrm{L})$ sodium acetate solutions were added. The absorption at $440 \mathrm{~nm}$ was read after $2.5 \mathrm{~h}$ at $20^{\circ} \mathrm{C}$. Extract samples were evaluated at a final concentration of $0.1 \mathrm{mg} /$ $\mathrm{ml}$. Total flavonoid content was calculated as quercetin ( $\mathrm{mg} / \mathrm{g})$ using the following equation based on the calibration curve: $\mathrm{y}=0.0255 \mathrm{x}, \mathrm{R}^{2}=0.9812$, where $\mathrm{x}$ was the absorbance and was the quercetin equivalent ( $\mathrm{mg} / \mathrm{g})$.

\section{Determination of total proanthocyanidins}

Determination of proanthocyanidin was based on the procedure reported by Sun et al., [25]. A volume of $0.5 \mathrm{ml}$ of $0.1 \mathrm{mg} / \mathrm{ml}$ of extract solution was mixed with $3 \mathrm{ml}$ of $4 \%$ vanillin-methanol solution and $1.5 \mathrm{ml}$ hydrochloric acid; the mixture was allowed to stand for $15 \mathrm{~min}$. The absorbance was measured at $500 \mathrm{~nm}$. Extract samples were evaluated at a final concentration of $0.1 \mathrm{mg} / \mathrm{ml}$. Total proanthocyanidin content were expressed as catechin equivalents $(\mathrm{mg} / \mathrm{g})$ using the following equation based on the calibration curve: $\mathrm{y}=0.5825 \mathrm{x}, \mathrm{R}^{2}=0.9277$, where $\mathrm{x}$ was the absorbance and $\mathrm{y}$ is the catechin equivalent (mg/g).

\section{Determination of antioxidant activity \\ $A B T S$ radical scavenging assay}

For ABTS assay, the method of Re et al., [26] was adopted. The stock solutions included $7 \mathrm{mM}$ ABTS solution and 2.4 $\mathrm{mM}$ potassium persulfate solution. The working solution was then prepared by mixing the two stock solutions in equal quantities and allowing them to react for $12 \mathrm{~h}$ at room temperature in the dark. The solution was then diluted by mixing $1 \mathrm{ml}$ ABTS.+ solution with $60 \mathrm{ml}$ methanol to obtain an absorbance of $0.706 \pm 0.001$ units at $734 \mathrm{~nm}$ using the spectrophotometer. ABTS $\cdot{ }^{+}$solution was freshly prepared for each assay. Plant extracts $(1 \mathrm{ml})$ were allowed to react with $1 \mathrm{ml}$ of the ABTS.+ solution and the absorbance was taken at $734 \mathrm{~nm}$ after $7 \mathrm{~min}$ using the spectrophotometer. The ABTS.+ scavenging capacity of the extract was compared with that of BHT and percentage inhibition calculated as ABTS radical scavenging activity $(\%)=\left[\left(\mathrm{Abs}_{\text {control }}-\mathrm{Abs}_{\text {sample }}\right)\right] /\left(\mathrm{Abs}_{\text {control })}\right] \times 100$ where $\mathrm{Abs}_{\text {control }}$ is the absorbance of ABTS radical + methanol; $\mathrm{Abs}_{\text {sample }}$ is the absorbance of ABTS radical + sample extract/standard.

\section{DPPH radical scavenging assay}

The effect of extracts on DPPH radical was determined using the method of Liyana-Pathiranan \& Shahidi [27]. A solution of $0.135 \mathrm{mM}$ DPPH in methanol was prepared and $1.0 \mathrm{ml}$ of this solution was mixed with $1.0 \mathrm{ml}$ of extract in methanol containing $0.02-0.1 \mathrm{mg}$ of the extract. The reaction mixture was vortexed thoroughly and left in the dark at room temperature for $30 \mathrm{~min}$. The absorbance of the mixture was measured spectrophotometrically at $517 \mathrm{~nm}$. Ascorbic acid and BHT were used as references. The ability to scavenge DPPH radical was calculated by the following equation: DPPH radical scavenging activity (\%) $=\left[\left(\mathrm{Abs}_{\text {control }}-\mathrm{Abs}_{\text {sample }}\right)\right] /\left(\mathrm{Abs}_{\text {control }}\right] \times 100$ where $\mathrm{Abs}_{\text {con- }}$ trol is the absorbance of DPPH radical + methanol; $\mathrm{Abs}_{\text {sam- }}$ ple is the absorbance of DPPH radical + sample extract/ standard.

\section{Total antioxidant activity (FRAP assay)}

A modified method of Benzie \& Strain [28] was adopted for the FRAP assay. The stock solutions included $300 \mathrm{mM}$ acetate buffer (3.1 $\mathrm{g} \mathrm{CH}_{3} \mathrm{COONa}$ and $16 \mathrm{ml} \mathrm{CH}_{3} \mathrm{OOH}$ ), pH 3.6, 10 mM TPTZ (2, 4, 6-tripyridyl-s-triazine) solution in $40 \mathrm{mM} \mathrm{HCl}$, and $20 \mathrm{mM} \mathrm{FeCl}_{3} \cdot 6 \mathrm{H}_{2} \mathrm{O}$ solution. The fresh working solution was prepared by mixing $25 \mathrm{ml}$ acetate buffer, $2.5 \mathrm{ml} \mathrm{TPTZ}$, and $2.5 \mathrm{ml} \mathrm{FeCl}_{3} \cdot 6 \mathrm{H}_{2} \mathrm{O}$. The temperature of the solution was raised to $37^{\circ} \mathrm{C}$ before using. Plant extracts $(150 \mu \mathrm{L})$ were allowed to react with $2850 \mu \mathrm{l}$ of the FRAP solution for $30 \mathrm{~min}$ in the dark condition. Readings of the colored product (ferrous tripyridyltriazine complex) were taken at $593 \mathrm{~nm}$. The standard curve was linear between 200 and $1000 \mu \mathrm{M} \mathrm{FeSO}_{4}$. Results are expressed in $\mu \mathrm{M}$ Fe (II)/g dry mass and compared with that of BHT, ascorbic acid and catechin. 


\section{Statistical analysis}

The experimental results were expressed as mean \pm standard error of mean (SEM) of three replicates. Where applicable, the data were subjected to one way analysis of variance (ANOVA) and differences between samples were determined by Duncan's Multiple Range test using the Statistical Analysis System (SAS 1999) program. P Values $<0.05$ were regarded as significant and $P$ values $<0.01$ as very significant.

\section{Results}

Total phenolic, flavonoids, flavonols, and proanthocyanidin contents

Results obtained in the present study revealed that the level of these phenolic compounds in A. gummifera and A. oppositifolia was significant with the extract from the stem of A. oppositifolia showing higher level of phenolic compounds (Table 1). When compared to the standard compounds used in this study, the levels in the plant extracts are significantly lower.

\section{Total antioxidant power (FRAP)}

The reducing ability of the extracts was in the range of 159.12 - $301.21 \mathrm{~mm}$ Fe (II)/g (Table 2). The FRAP values for the A. gummifera and A. oppositifolia extracts were significantly lower than that of ascorbic acid and catechin, but higher than that of BHT.

\section{ABTS radical scavenging activity}

A. oppositifolia and A. gummifera extracts were fast and effective scavengers of the ABTS radical (Fig 1) and this activity was comparable to that of BHT. At $0.08 \mathrm{mg} / \mathrm{ml}$ the percentage inhibition was 99.0, 94.2 and $96.8 \%$ for $A$. oppositifolia, A. gummifera and BHT respectively. On the other hand, at $0.1 \mathrm{mg} / \mathrm{ml}$, the percentage inhibition was 90.5, 95.5 and $99.3 \%$ for A. oppositifolia, A. gummifera and BHT respectively.

\section{DPPH radical scavenging activity}

Figure 2 shows the dose-response curve of DPPH radical scavenging activity of the methanolic extracts of the stem

Table I: Polyphenol contents of the methanol extracts of the stems of A. oppositifolia and Adenia gummifera.

\begin{tabular}{lll}
\hline Phenolics & A. oppositifolia & A. gummifera \\
\hline Total polyphenol $^{\mathrm{a}}$ & $9.51 \pm 2.12$ & $8.24 \pm 0.77$ \\
Flavonoids $^{\mathrm{b}}$ & $0.81 \pm 0.02$ & $1.11 \pm 0.02$ \\
Total Flavonolc $^{\mathrm{c}}$ & $1.01 \pm 0.37$ & $1.11 \pm 0.02$ \\
Proanthocyanidins $^{\mathrm{d}}$ & $0.71 \pm 0.20$ & $1.14 \pm 0.3 \mathrm{I}$ \\
\hline
\end{tabular}

$(\mathrm{n}=3, \mathrm{X} \pm$ SEM).

aExpressed as $\mathrm{mg}$ tannic acid/g of dry plant material.

bExpressed as $\mathrm{mg}$ quercetin/g of dry plant material.

cExpressed as $\mathrm{mg}$ quercetin/g of dry plant material.

dExpressed as $\mathrm{mg}$ quercetin/g of dry plant material
Table 2: Ferric reducing antioxidant property (FRAP) of the stem extracts of $A$. oblongifolia and $A$. gummifera.

\begin{tabular}{ll}
\hline Extracts & FRAP $(\mu \mathrm{mol} \mathrm{Fe}(\mathrm{II}) / \mathrm{g})$ \\
\hline A. oblongifolia & $301.21 \pm 12.96$ \\
A. gummifera & $159.12 \pm 7.58$ \\
Ascorbic acid & $1632.1 \pm 16.95$ \\
BHT & $63.46 \pm 2.49$ \\
Catechin & $972.02 \pm 0.61$ \\
Quercetin & $3107.29 \pm 31.28$ \\
\hline
\end{tabular}

$(n=3, X \pm S E M)$.

of Acokanthera oppositifolia and Adenia gummifera, compared with BHT and ascorbic acid. It was observed that methanol extract of $A$. oppositifolia had higher activity than that of A. gummifera. At a concentration of $0.1 \mathrm{mg} / \mathrm{ml}$, the scavenging activity of methanol extract of A. oppositifolia reached $70 \%$, while that of $A$. gummifera methanol extract was only $60 \%$.

\section{Discussion}

Total phenolic, flavonoids and proanthocyanidin contents Polyphenols are the major plant compounds with antioxidant activity. This activity is believed to be mainly due to their redox properties [29], which play an important role in adsorbing and neutralizing free radicals, quenching singlet and triplet oxygen, or decomposing peroxides. The results from this study strongly suggest that phenolics are important components of these plants, and some of their pharmacological effects could be attributed to the presence of these valuable constituents.

\section{Total antioxidant power (FRAP)}

The antioxidant potentials of A. gummifera and A. oppositifolia extracts were estimated from their ability to reduce TPRZ-Fe (III) complex to TPTZ-Fe (II). Antioxidant activity increased proportionally to the polyphenol content. According to recent reports, a highly positive relationship between total phenols and antioxidant activity appears to be the trend in many plant species [30].

\section{ABTS radical scavenging activity}

Proton radical scavenging is an important attribute of antioxidants. ABTS, a protonated radical, has characteristic absorbance maxima at $734 \mathrm{~nm}$ which decreases with the scavenging of the proton radicals [31]. The 2,2'-azinobis-3- ethylbenzothiazoline-6-sulfonic acid (ABTS) activities of the 2 plant extracts were similar and comparable to that of BHT. Higher concentrations of the extracts were more effective in quenching free radicals in the system.

\section{DPPH radical scavenging activity}

The effect of antioxidants on DPPH is thought to be due to their hydrogen donating ability [32]. Although the DPPH radical scavenging abilities of the extracts were sig- 


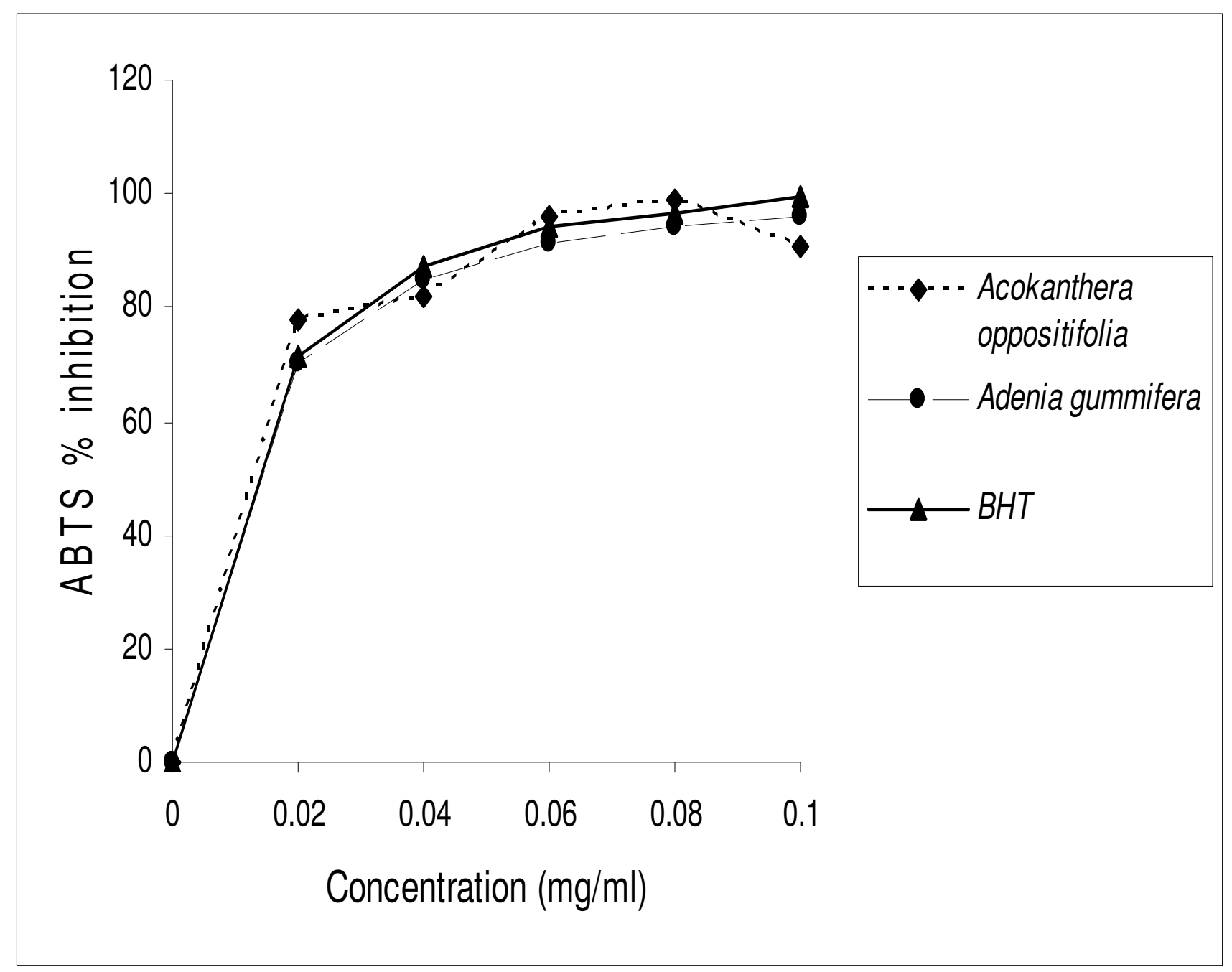

Figure I

ABTS scavenging activity of the methanol extracts of the stems of Acokanthera oppositifolia and Adenia gummifera.

nificantly lower than those of ascorbic acid and BHT, it was evident that the extracts did show the proton-donating ability and could serve as free radical inhibitors or scavengers, acting possibly as primary antioxidants.

The scavenging of the ABTS+ radical by the extracts was found to be higher than that of DPPH radical. Factors like stereoselectivity of the radicals or the solubility of the extract in different testing systems have been reported to affect the capacity of extracts to react and quench different radicals [33]. Wang et al., [34] found that some compounds which have $\mathrm{ABTS}^{+}$scavenging activity did not show DPPH scavenging activity. In this study, this was not the case. This further showed the capability of the extracts to scavenge different free radicals in different systems, indicating that they may be useful therapeutic agents for treating radical-related pathological damage.

\section{Conclusion}

Although in most cases, the biological activities of the extracts from the stems of A. oppositifolia and A. gummifera are not as high as those of the standard compounds used in this study, the present results indicate clearly that the extracts from these plants possess antioxidant properties and could serve as free radical inhibitors or scavengers, acting possibly as primary antioxidants. This study has to some extent validated the medicinal potential of the stems of Acokanthera oppositifolia and Adenia gummifera. 


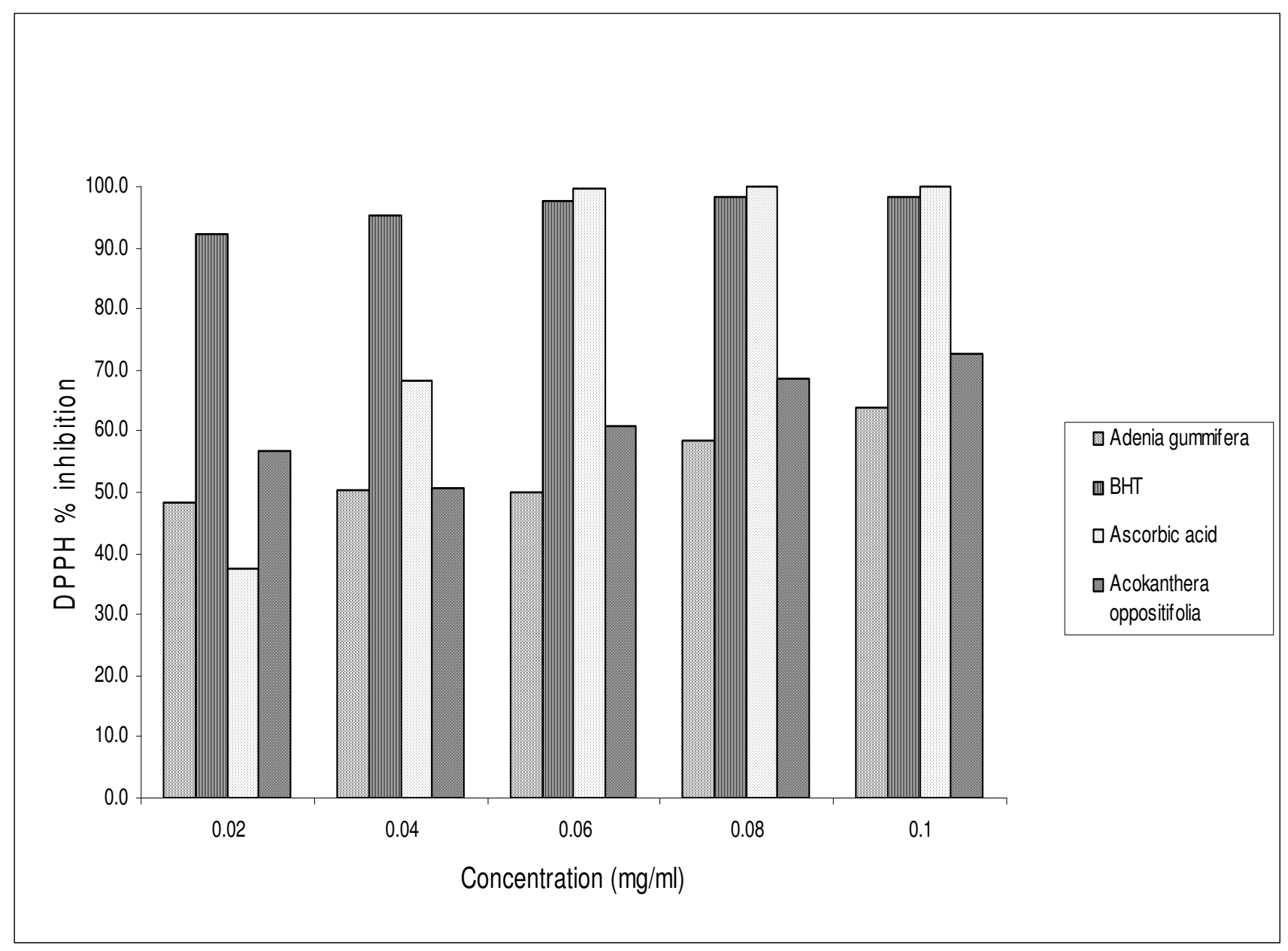

Figure 2

DPPH scavenging activities of Acokanthera oppositifolia and Adenia gummifera.

\section{Competing interests}

The authors declare that they have no competing interests.

\section{Authors' contributions}

AAA: Prepare the extract, carried out the assays and drafted the manuscript. FOJ: Carried out the assay. AJA: Coordinated the study. PJM: Provided the grants for the study and also coordinated the study. All authors read and approved the final manuscript.

\section{Acknowledgements}

The authors wish to acknowledge the financial support of Govan Mbeki Research and Development Center (GMRDC) of the University of Fort Hare for funding the research.

\section{References}

I. Steyn DG: The toxicology of plants in South Africa. Central News Agency, South Africa; 1934:23-31.

2. Verdcourt B, Trump EC: Common poisonous plants of East Africa. Collins, London; 1969:4-6.
3. Neuwinger HD: African Ethnobotany: Poisons and Drugs: Chemistry, Pharmacology and Toxicology. Chapman and Hall, Germany; 1996:34-37.

4. Van Wyk B, Van Heerden F, Van Oudtshoon B: Poisonous plants of South Africa. Briza Publications, Pretoria; 2002:46-49.

5. Kellerman TS, Coetzer JAW, Naude TW: Plant poisonings and mycotoxicoses of livestock in Southern Africa. Oxford University Press, Cape Town; 1988:25-26.

6. Watt JM, Breyer-Brandwijk MG: The medicinal and poisonous plants of Southern and Eastern Africa. 2nd edition. Livingstone, London; 1962:15-18.

7. Dold AP, Cocks ML: Traditional veterinary medicine in the Alice district of the Eastern Cape Province, South Africa. South African Journal of Science 200I, 97:I-7.

8. Schlegel W, Tamm C, Reichstein T: The constitution of Acovenoside A. Helv Chimini Acta 1955, 38:1013-1025.

9. De Villers JP: The cardiac glycosides of Acokanthera oblongifolia. Journal of South African Chemical Institute 1962, I5:82-84.

10. Gasperi-Campani A, Barbieri L, Lorenzoni E, Montanaro L, Sperti S, Bonetti E, Stirpe F: Modectin, the toxin of Adenia digitata. Purification, toxicity and inhibition of protein synthesis in vitro. Biochemistry Journal 1978, 174:49|-496.

II. Spencer KC, Seigler DS: Tetraphyllin B and epi-tetraphyllin B from Adenia glauca Schinz. Onderstepoort Journal of Veterinary Research 1982, 49:137-138. 
12. Spencer KC, Seigler DS: Tetraphyllin B from Adenia digitata. Phytochemistry 1982, 21:653-655.

13. Fullas F, Brown DM, Wani MC, Wall ME, Chagwedera TE, Farnsworth NR, Pezzuto JM, Kinghorn AD: Gummiferol, a cytotoxic polyacetylene from the leaves of Adenia gummifera. Journal of Natural Product 1995, 58(10): 1625-1628.

14. Rang HP, Dale MM, Ritter JM, Moore PK: Pharmacology. Churchill Livingstone, Edinburgh; 2003:219.

15. Cheeseman $\mathrm{KH}$, Scater TF: Free radical in medicine. In British Medical Bulletin Volume 49. Churchill Livingstone, London; 2003:479-724.

16. Lollinger J: Free radicals and food additives. Taylor and Francis London; 1981:21.

17. Tutour BL: Antioxidative activities of algal extracts. Synergistic effect with vitamin E. Phytochemistry 1990, 29:3759-3765.

18. Raj KJ, Shalini K: Flavonoids-a review of biological activities. Indian Drugs 1999, 36:668-676.

19. Badami S, Gupta MK, Suresh B: Antioxidant activity of the ethanolic extract of Striga orobanchioides. Journal of Ethnopharmacology 2003, 85:227-230.

20. Masika PJ, Afolayan AJ: An ethnobotanical study of plants used for the treatment of livestock diseases in the Eastern Cape Province, South Africa. Pharmaceutical Biology 2003, 4I:|6-2I.

21. Taylor RSL, Edel F, Manandhar NP, Towers GHN: Antimicrobial activity of southern Nepalese medicinal plants. Journal of Ethnopharmacology 1996, 45:67-70.

22. Wolfe K, Wu X, Liu RH: Antioxidant activity of apple peels. Journal of Agriculture and Food Chemistry 2003, 5 I:609-6I4.

23. Ordon Ez AAL, Gomez JD, Vattuone MA, Isla MI: Antioxidant activities of Sechium edule (Jacq.) Swart extracts. Food Chemistry 2006, 97:452-458.

24. Kumaran A, Karunakaran RJ: In vitro antioxidant activities of methanol extracts of Phyllanthus species from India. Volume 40. Lebens-Wiss Technologie; 2007:344-352.

25. Sun JS, Tsuang YW, Chen IJ, Huang WC, Hang YS, Lu FJ: An ultraweak chemiluminescence study on oxidative stress in rabbits following acute thermal injury. Burns 1998, 24:225-231.

26. Re R, Pellegrini N, Proteggente A, Pannala A, Yang M, Rice-Evans C Antioxidant activity applying an improved ABTS radical cation decolorization assay. Free Radical Biology and Medicine 1999 , 26: $123|-| 237$

27. Liyana-Pathiranan CM, Shahidi F: Antioxidant activity of commercial soft and hard wheat (Triticum aestivum $L$ ) as affected by gastric pH conditions. Journal of Agriculture and Food Chemistry 2005, 53:2433-2440.

28. Benzie IFF, Strain JJ: The ferric reducing ability of plasma (FRAP) as a measure of "antioxidant power": the FRAP assay. Analytical Biochemistry 1996, 239:70-76.

29. Zheng W, Wang SY: Antioxidant activity and phenolic compounds in selected herbs. Journal of Agriculture and Food Chemistry 200I, 49:5I65-5I70.

30. Oktay M, Gulcin I, Kufrevioglu Öl: Determination of in vitro antioxidant activity of fennel (Foeniculum vulgare) seed extracts. Volume 36. Lebens-Wiss Technologie; 2003:263-27I.

31. Mathew S, Abraham TE: In vitro antioxidant activity and scavenging effects of Cinnamomum verum leaf extract assayed by different methodologies. Food Chemistry and Toxicology 2006, 44:198-206.

32. Baumann J, Wurn G, Bruchlausen FV: Prostaglandin synthetase inhibiting $\mathrm{O}_{2}^{-}$radical scavenging properties of some flavonoids and related phenolic compounds. Deutsche Pharmakologische Gesellschaft Abstracts of the 20th spring meeting, NaunynSchmiedebergs Abstract No: R27 cited in Arch Pharmacologia 1979, 307:RI-R77.

33. Yu L, Haley S, Perret J, Harris M, Wilson J, Qian M: Free radical scavenging properties of wheat extracts. Journal of Agriculture and Food Chem 2002, 50:1619-1624.

34. Wang M, Li J, Rangarajan M, Shao Y, La Voie EJ, Huang T, Ho C: Antioxidative phenolic compounds from Sage (Salvia officinalis). Journal of Agriculture and Food Chemistry 1998, 46:4869-4873.

\section{Pre-publication history}

The pre-publication history for this paper can be accessed here: http://www.biomedcentral.com/1472-6882/8/54/prepub

Publish with Biomed Central and every scientist can read your work free of charge

"BioMed Central will be the most significant development for disseminating the results of biomedical research in our lifetime. "

Sir Paul Nurse, Cancer Research UK

Your research papers will be:

- available free of charge to the entire biomedical community

- peer reviewed and published immediately upon acceptance

- cited in PubMed and archived on PubMed Central

- yours - you keep the copyright
BioMedcentral 